\title{
RELIGION AS A CULTURAL SYSTEM: A MULTICULTURALISM EDUCATION MODEL IN BALI BASED ON LOCAL TRADITION
}

\author{
Made Saihu1, Hamdani Anwar ${ }^{2}$, Suhada $^{3}$, Abd. Aziz ${ }^{4}$, Lilis Fauziah Balgis ${ }^{5}$ \\ ${ }^{1}$ Institute of PTIQ Jakarta, Indonesia \\ ${ }^{2}$ State Islamic University of Syarif Hidayatullah Jakarta, Indonesia \\ ${ }^{3}$ Islamic College of Al-Hikmah Jakarta, Indonesia \\ ${ }^{4}$ Islamic College of Al-Amin, South Tangerang, Indonesia \\ ${ }^{5}$ University of Juanda Bogor, Indonesia
}

\begin{abstract}
This study discusses the harmony of Hindus and Muslims in Jembrana Bali is seen from a religious point of view as a cultural system involving both religious adherents. The Ngejot and Male traditions are local traditions that show this Hindu-Muslim harmony. Through the theoretical approach of religion as a cultural system, this ethnographic study emphasizes the importance of embodying religious traditions through local culture. Although the tradition of Male originates from the Islamic tradition, cultural influences are able to encourage adaptation to Balinese customs so that harmony is more easily maintained. Here the Muslims understand their position to protect and respect the dominant culture adhered to by the majority of Hindus in Jembrana Bali. The same thing is done by Hindus who try to show a good response to Muslims by involving them in the tradition of Ngejot which was originally a Hindu tradition of worshiping God, to some extent shown by adjustments so as not to conflict with Muslim beliefs. A wealth of local traditions that shows a portrait of harmony between religious communities in Indonesia and becomes a model for multiculturalism education based on local traditions.
\end{abstract}

Keywords: Education, Local Traditions, Multiculturalism, Culture

Article Received: 20 September 2020, Revised: 30 November 2020, Accepted: 18 December 2020

\section{INTRODUCTION}

Based on the analysis described by Michalinos $\mathrm{Z}$ and Zvi Bekerman, in the Journal of Peace Education in the Present: dismantling and reconstructing some fundamental theoretical premises, concludes that critical culture can be a solution to conflict and be a substance in peace education without involving religious elements (Michalinos Z, 2013). This study may be justified, especially if you look at the facts in the State of Kenya which make religion the basis for carrying out acts of terrorism associated with the Al-Shabaab group and it is increasingly clear that religion is a source of conflict (P., 2019). This fact, an opinion is built that religion is a source of social and cultural conflict as a solution to the phenomenon of radicalism. In fact, religion and culture are two very close entities. Religion represents ethics and culture represents aesthetics (Beyers, 2017). These two entities become social capital that can create various situations between harmony and discrimination in Indonesia, especially in Province of Bali.

The relationship between religion and culture has indeed been done a lot, one of which is a study conducted by Kobylarek which states that religion and culture are two entities that stand parallel (Kobylarek, 2014). Religion and culture are also two forces that can free humans from ignorance, oppression, and torment, especially for Muslims (Marc Helbling, 2016). Then, in the midst of the proliferation of studies on Bali from various social and perspectives humanities, scholars have studied quite a lot. Generally, scholars' studies focus on historical aspects, majority-minority issues, regional autonomy and postBali bomb tensions (Saihu, 2020; Vickers, 1987; Wikan, 1990). Several recent scholars have also explained the role of culture and religion in Bali (Basyir, 2016; Karim, 2016; Maknun, 2018; I. M Pageh, 2018; I Made Pageh, 2013; Rusmayani, R., \& Gunawan, 2018; Sabarudin dan Mahmud Arif, 2019). However, not many explain the Hindu- Muslims in Bali in the perspective of Religion as a cultural system are one of the factors supporting harmony between Hindus and Muslims.

This study explains the importance of the perspective of religion as a cultural system that adorns the various Hindu-Muslim traditions in Jembrana Bali in two community traditions, they are Ngejot and Male. Another way of looking at local traditions and Hindu-Muslim harmony in an area that is dominated by cultural expressions of religion those are guarded and respected by all adherents of that religion. Can this perspective really create harmony between Hindus and Muslim Jembrana? And whether this point of view becomes a model of multiculturalism education, which is a model of education in a broad sense, not just to get a scholarly title, but education that aims to instill religious and cultural values to encourage the emergence of superior culture and civilization and be proud of the citizens, not only sourced from regional culture, but also from elements.

This anthropological study was carried out by 
using the approach of the theory of religion as a cultural system from Clifford Geertz to see firsthand the practice of harmony in Balinese society (Geertz, 1973). This theory sees that harmony between ethnic groups and religions can be created when religion becomes a cultural system that dominates all individual attitudes in it. In practice, when religion becomes a system, many among the religious community, especially Hinduism, because they have too much respect for this culture, cannot distinguish which religion comes from God and which crocodiles are human creations. Although this phenomenon is confused, in reality, the Hindu and Muslim communities in Jembrana Bali are becoming more and more harmonious through the application of this kind of perspective. The author conducted ethnographic research steps in the field around January-June 2019, including conducting a series of interviews with Hindu and Muslim religious leaders in Jembrana.

\section{METHOD}

\section{Participant}

This research is a field research, exploratory in nature which aims to obtain an overview of the multicultural education model in Jembrana Bali by using the approach of religion as a cultural system (Bailey, 1982). The primary data source is the result of in-depth interview observations and documentation from two communities (Hindu and Muslim) in the world of education and social society. Informants in the Muslim community consist of; religious leaders, leaders of Islamic boarding schools, administrators of the Indonesian Ulama Council (MUI) Jembrana Bali, and traditional community leaders. Meanwhile, the Hindu community consists of Hindu Religious Leaders (Pemangku, Pandita, Balian), the Ministry of Religion institution in Jembrana Bali, Jembrana Regency Regional Government (Pemda) institutions, school principals, and the Bali Religious Communication Forum (FKUB), chairman of Parisada Hindu Dharma. Indonesia (PHDI).

The informants from the Muslim community are: 1) KH. Ahmad Damanhuri. He is a Muslim religious leader in Jembrana Regency, Bali. His strength is an indicator to become the main informant in this study, because he is a living witness and the one who understands the relationship between Muslims and Hindus in Jembrana Bali; 2) KH. Ahmad Muzakki, he is the caretaker of the Manba 'ul Ulum Negara Islamic Boarding School. Boarding School of Manba 'ul Ulum is the largest and oldest Islamic boarding school in Jembrana Bali, besides that, it is also a symbol of da'wah that builds multiculturalism which is also the chairman of the Indonesian Ulama Council (MUI); 3) Dr. KH. Fathurrahim, M.Pd.I, leader of the Nurul Ikhlas Negara Islamic Boarding
School who is also an interfaith figure in Jembrana Regency and is also the vice chairman of the religious community communication forum in Jembrana Regency. Furthermore, informants from the Hindu community consisted of: 1) Ida Bagus Indagosa, he is a Hindu community figure who was also the initiator of the idea of multiculturalism in Jembrana Bali; 2) Ida Bagus Komang Dharma Santia Putra, he is a Balinese cultural observer; 3) I Komang Arsana, he is the Chairperson of the Jembrana Religious Communication Forum (FKUB); and 4) I Made Kembang Hartawan vice-regent of Jembrana Regency

\section{Interpretation}

The method used in this research is the case study method. As one variant in qualitative research, case studies provide a comprehensive description and explanation of a particular setting, document, or a particular event (Knopp, 1998). By studying maximally about this, the researcher wants to get a complete and in-depth view of the actualization of the multiculturalism education model through the approach of religion as a cultural system. The advantages of the case study method include: 1) The main tool for EMIK researchers, that is presenting the views of the subject under study; 2) Presenting a comprehensive description of what is experienced in everyday life; 3) Effective means of showing the relationship between researchers and respondents; 4) Allows to find internal consistency which is not consistency of style and consistency of factual, but also trust-worthiness; 5) Open to an assessment of the context which contributes to the meaning in that context (Guba, 1985)

\section{Procedure}

Data collection technique is carried out by: observation, in-depth interviews, and documentation. Of the two communities, they are Hindu and Muslim. Observation, that is: directly observing the educational process and the interaction between religions and various other activities between the Hindu and Muslim communities in the Jembrana area. These observations are directed at understanding the setting of education and the social conditions of the community. So is to understand the sociological conditions of society as a forum for religious multiculturalism education occurring in the midst of society, as well as understanding the possibility of social conflict that could be caused by different theological understandings and their implications in the context of religious pluralism education in the Jembrana community.

The next technique is an in-depth unstructured interview. This technique was chosen because it allows free interaction between the author and the 
informant. This is based on the definition that unstructured interviewing is a research technique that allows informants to define themselves and their environment by using their own terms, of course based on their culture and traditions (Mulyana, 2002). Complementing the various techniques above, documentation study is needed especially to enrich the theoretical foundations and exploration of past data related to the themes in this research. That is data collection based on written documents in the form of a learning curriculum, historical records or certain symbols. In relation to the focus of this research, the documentation method is used to reveal data about the implementation of religious pluralism education and its implications for social interactions between Hindus and Muslims in Jembrana Regency, Bali.

\section{Data Analysis Techniques}

Data analysis in this study refers to the Milles and Hubermen data analysis procedures. According to Milles and Hubermen, data analysis in qualitative research generally starts from data collection, data reduction, data presentation, and drawing conclusions or verification. The methodological elements in this procedure at the same time reflect the interactive components of the analysis (Michael, 1992). The analytical activities during the data collection are intended to establish focus in the field, compile preliminary findings, make plans for the next data collection, develop analytical statements and determine subsequent data targets. Then from the data collection, it is reduced (data reduction) as an effort to choose a focus on simplification, and to extract field data. In the data reduction process, researchers made a selection or mapping by making categories based on the problems being studied. After the results of a set of reductions, the next step is to present a set of compiled information or data, the possibility of drawing conclusions. Conclusions are also verified during research activities taking place in the field, so that it will be clear how valid the characteristics of the data are.

\section{RESULTS}

\section{Religion as a Human Cultural System}

In anthropological studies, the perspective of the theory of religion as a cultural system is used to explain the relationship between religion and culture. Clifford Geertz (1926-2006), a prominent American anthropologist, explained this theory in the context of studying the relationship between religion and culture in Indonesia. According to him, religion as a cultural system because religion: (1) a symbol system that aims to (2) create strong feelings and motivations, spread easily and are not easily lost in a person (3) by forming a conception of a general order of existence and (4) attaching this conception to factual emanations (5) and in the end this feeling and motivation will be seen as a unique reality (Geertz, 1993).

More explanation in this argument, 1) As a symbol system it means anything that gives an idea an idea. For example a circle object to pray for Buddhists, or an event of crucifixion: a ritual such as the cross of Mitzvah and / or acts that can bring solemnity; 2) When it is said that symbols create strong feelings and motivation, they are easily spread and are not easily lost in a person. The point is that religion can motivate someone to do something with the guidance of good and correct values that come from religion. It can be seen that Jews have a high desire to visit Jerusalem, Muslims have a strong desire to go to Mecca, and once Christians have a high desire to visit Bethlehem, they will prepare everything to make this dream come true, so that can have religious experience in these sacred places. These feelings are difficult to define and also difficult to control; 3) Forming a conception of a general order of existence. Geertz, wants to state that religion tries to provide an explanation of "life and death" about the world. The point is that religion is not intended to express about everyday life, such as sports, games, fashion, clothing, but rather focuses on the final meaning, that is a definite goal for the world. Religion will show its identity when people intellectually face problems that cannot be fully understood, or emotionally they face problems that cannot be avoided, and or morally they find evil everywhere that they cannot accept. It is at moments like these that religion will become clear, even though it sometimes appears to be contradicting reality; 4) Attaching this conception to factual emanations. In this case, Geertz's intention is that religion becomes a series of motivations to achieve a moral ideal which in turn will give birth to unique religious realities that are traditional in nature and far from being a rational religion. This is the fifth core of Geertz's statement that religion can become a cultural system (Pals, 2011).

Geertz then gave an example of how, for example, Balinese in general make up their culture or tradition in socializing or manifesting their religious activities without involving institutional elements of their respective religious identities. Although this phenomenon is included in the traditional model of diversity by Webber, this method is one of the means to minimize disharmony between religious communities in Jembrana Bali. When religion presents institutional elements, the Balinese feel "less satisfied" when there is an "internal conversion" of their religion and traditions, from a religion that with traditional worship turns to rational worship, which in its religious activities requires well-organized symbols (Geertz, 1993). When diversity presents institutional 
symbols, what happens is the impression of compartmentalizing certain identities which can present negative relationships in society.

Religion and cultural relations in traditional religions in Bali become a bridge for Multiculturalism in social life. Multiculturalism is a necessity, especially in the Indonesian context. Therefore, there must be a formula to reconcile and unite them. In modern society, multiculturalism is even more complex. Because new cultures continue to emerge as a result of unstoppable access to communication and information. That is, nervousness, fulfillment of one's own understanding and considering others as heretical groups must be eradicated. Because in essence there is no truth whatsoever to step on and negate other truths (Mubit, 2016).

Anthropological studies are inseparable from studies of multiculturalism, especially in the context of religious and cultural relations in Indonesia. This could be a pattern of Islamic diversity in Indonesia which is termed the Islam Nusantara. Islam Nusantara Islam is a religion that is friendly to culture. People are kaffah Muslims but do not leave their cultural traditions, it is the tradition or culture that makes them stronger and believe in the religion they believe in. In Nusantara Islam, it is described how teachings that are normatively derived from God are accommodated in the culture that comes from humans without losing their respective identities. Nusantara Islam tries to make religion and culture not overpower each other, but instead manifests in a pattern of religious reasoning that no longer takes its authentic form from religion and seeks to bring together the bridge that has been separating religion and culture, so that there is no longer any conflict between religion and culture (Astuti, 2017).

Thus, the theory of religion as a cultural system is very important in analyzing the relationship between ethnicities and religions in Indonesia. He can explain how harmonious relations between ethnicities and religions can be maintained by giving respect to the dominant religion expressed through the culture in which they live together. So that several cases of conflict in the name of religion, such as in Sambas and Ambon, Poso, Manislor, Cikeusik, Tolikara, Sampang, Tanjungbalai and the issue of religious blasphemy by Ahok show a lack of respect for the dominant culture among tribal members and religious followers (Vitchek, 2012).

\section{Multiculturalism Education Model Based on Local Traditions in Jembrana Bali}

As already explained, Hindu-Muslims in Jembrana have historically been characterized by cooperation and conflict. However, over time, cooperation between the two religions has been continuously strengthened, one of which is through local traditional practices. Local traditions are used as a socio-cultural mechanism in building brotherhood and solidarity between religious adherents (Azra, 2002) It cannot be separated from what is called local wisdom as the dominant culture prevailing in Balinese society as reference in behavior. Balinese people generally have some principle of local wisdom as an expression of Nyame slam/Bali/Hindu (Islamic civil / Bali / Hindu), menyama braya (perceive others as your own), metetulung (mutual help) is requested (ngidih tulung) or unsolicited (mesuaka), paras-poros (mutual borrowing tradition), nandu, ngadas, mekadasang (working on rice fields or livestock), ngayah (mutual cooperation) and others (I Gede Suwindia, 2012). This local wisdom is then manifested in various traditional practices that reflect the harmony between ethnicities and religions in Bali.

There are several local traditions in Jembrana that have become important channels for strengthening Hindu-Muslim relations, including the traditions of Ngejot and Male. These various traditions are carried out by expressing religion in the prevailing culture in Jembrana. Therefore, although some of these traditions were originally part of the Islamic tradition, in practice they are still influenced by the dominant culture in Bali as a form of this award. On the other hand, even though some of these traditions have Hindu origins, Muslims will also try to respect them by maintaining these traditions as a form of harmony.

\section{Tradition Ngejot, Food and Local Harmony \\ Ngejot is a tradition of sharing food (jotan)} between Hindu Muslims during wedding, birth or religious ceremonies. This tradition is carried out when one of the Hindus or Muslims wants to carry out a certain traditional or religious ceremony. He will invite the family and neighbors of other parishioners to send food as an expression of gratitude. Invited residents will also attend with basic necessities in the form of rice, sugar, coffee and so on. When Hindus carry out Galungan or Kuningan holidays, for example, they will send food to their fellow Muslims with halal food. On the other hand, Muslims will also send food to their Hindu brothers. Likewise, when Muslims fast in the month of Ramadan, one form of respect given by Hindus to Muslims is to do Ngejot by giving food to break, such as ketupat, fruit, es crank (young coconut water) and so on. An intercultural communication between Hindu-Muslim people that reflects harmony and local wisdom through foods (Sumiati, 2017). 


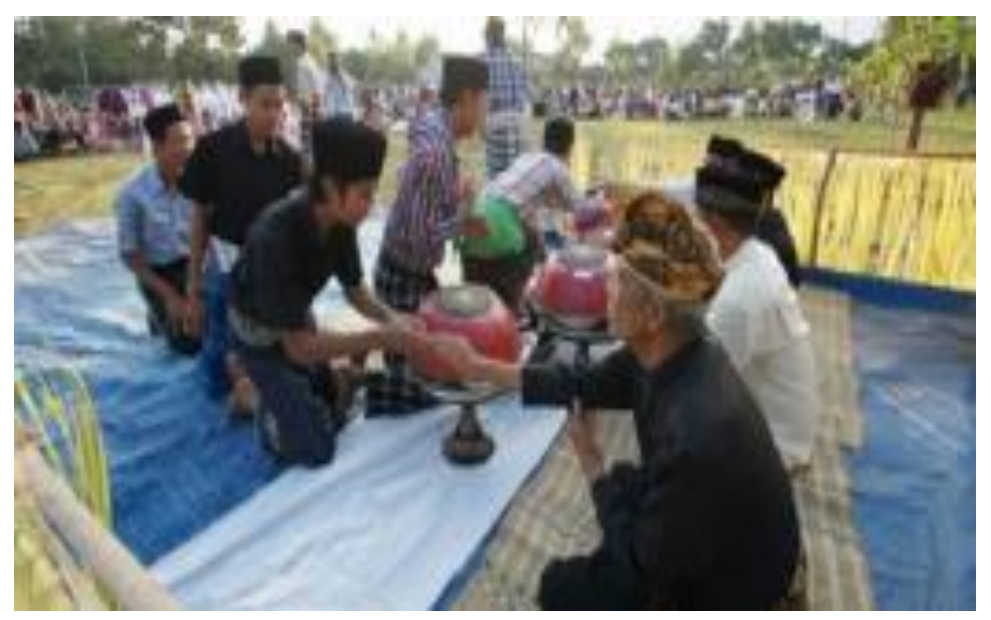

The tradition of sharing food in Ngejot is recognized by I Komang Arsana as Chairperson of Parisada Hindu Dharma Indonesia and Chair of FKUB Jembrana. He said: "Often when I was celebrating Galungan or Kuningan and other celebratory events, I always thought of boosting or sending food to my Muslim brothers and sisters (equal to braya) as a form of sima krama dharma santhi (gathering), of course. the food that I will give is not against Islamic law. Therefore, the positive impact oftradition ngejot thisis tremendous in maintaining harmony and strengthening the sense of brotherhood between fellow religious communities. " (Interview with I Komang Arsana, April $7^{\text {th }}$ 2019) This was also acknowledged by Ali Rahman, Head of Dusun Kelapa Balian, who stated that tradition of Ngejot means of strengthening human (ukhuwah insaniyah) and fellow countrymen (ukhuwah wathaniyyah) (Interview with Ali Rahman, April $7^{\text {th }}$ 2019)

This statement shows that Hindu-Muslim harmony in Jembrana is reflected in the tradition of eating food in Ngejot that respects other religions. Hindus will provide food that is not considered haram in the teachings of Islamic law, such as groceries. Even though on Galungan, Hindus slaughter pigs, they will not share them with Muslims, because they respect the teachings of Islam that prohibit these animals. Therefore, as in other areas in Indonesia such as Catholic-Muslims in Manggarai, East Nusa Tenggara (NTT), who practice the tradition of woni (eating together), food can become a symbol of a community's identity in strengthening harmony between religious communities (Yohanes S Lon, 2019).

Not only in the arrangement of food in the tradition of Ngejot, efforts to respect each other between Hindus and Muslims in Jembrana are more broadly seen in animal slaughter ceremonies. The relatively close proximity of the domicile and places of worship for Hindu-Muslims have encouraged some adjustments in certain rituals. For example, the people of the State whose position of the mosque and the temple are close together make the ritual of slaughtering animals replaced with other animals so as not to offend each other. When Hindus commemorate Galungan, they do not slaughter pigs in honor of Muslims which is forbidden for them. On the other hand, when Muslims commemorate Eid al-Adha, they do not slaughter cows but are replaced with goats or buffaloes in honor of Hindus who regard cows as purified animals.

According to I Made Kembang Hartawan, Deputy Regent of Jembrana, the harmony between religious communities in Jembrana as shown in the tradition of Ngejot is inseparable from the existence of maturity in religion and an understanding of the value of diversity. Maturity and understanding of the diversity of ethnicities and religions in Bali are running quite well, so that they are wiser and more tolerant for the common good. Hartawan said: "There is no single religion that teaches violence. I often help build mosques, Islamic boarding schools, prayer rooms, even though I am a Hindu, because for me, heaven and hell affairs let God rule, the important thing is that we do good to others. " Interview with I Made Kembang Hartawan, April $14^{\text {th }}$ 2019). The same thing was conveyed by those who call it adaptive (adjustment) and culture adoptive (adopting good values). So that inter-religious life in Jembrana can run in harmony and harmony. (Interview with Ida Bagus Komang Dharma Santika Putra, May $1^{\text {st }} 2019$ ).

Historically, the tradition of Ngejot is actually a Balinese Hindu tradition that has been passed down from generation to generation. One month this tradition is only held on Hindu holidays, such as Galungan, Kuningan and Nyepi. The foods given are usually cakes, fruits, ointment, lawar and pork. This tradition was then carried out by Muslims in Bali. Since the arrival of Muslim immigrants from Bugis, Java, Sasak and other areas, they have then carried out this tradition, especially when welcoming Eid al-Fitr, Eid al-Adha or when holding religious ceremonies and 
other celebrations. It seems that there has been acculturation of traditions of Ngejot carried out in different religious traditions. Seen from the perspective of the theory of religion as a cultural system, thetradition ngejot shows how Muslims through this tradition practice religious teachings as the message conveyed by the Prophet Muhammad in his words, they are: that "the best action is to feed others, and say greetings to those who are you know and what you don't. " (Narrated by Bukhari: 12 and Muslim: 39)

Furthermore, Muslims try to understand the dominance of Balinese culture in their daily lives. Therefore, as a form of tolerance for religious and cultural diversity in Bali, Muslims try to apply this tradition in their religious ceremonies. The tradition of Ngejot determines the relationship between HinduMuslim religions in the form of making religion a Hindu local cultural system, so that Muslims as immigrants are able to have good relations with Hindus. Muslims try to adapt to the dominant local culture in the tradition of Ngejot so that inter-religious harmony in Jembrana Bali can be realized.

Therefore, although previous scholars emphasized the role of tradition in the context of inter-religious harmony in Bali, the perspective of religion as a cultural system was not found in their studies. This shows that Ngejot is a model of multiculturalism education, they are Hindu-Muslim relations which are not only marked by the existence of interfaith communication between friendship in
Islam and katwang asih in Hinduism (A. M. Saihu, 2019), but also a form of awareness of Muslims themselves as immigrant minorities in understanding the dominant culture in which they live. Therefore, it is misleading to say that boasting is considered part of the "da'wah arena" by some scholars (Baharun, 2018). A view that emphasizes the hidden interests of Islam unilaterally as opposed to the side of local wisdom has been escalating to strengthen harmony between Hindu-Muslim communities.

\section{Traditions Male, Eggs and Togetherness \\ Apart from the traditions of ngejot, the} harmonious relationship between Hindu Muslims is also seen in the tradition of male. Although this tradition developed in the Muslim community in Jembrana, in practice, Hindus were also involved in its implementation. The tradition is male usually carried out in commemorating the birth or birthday of the Prophet Muhammad. The term male refers to the decoration of boiled eggs without the skin being peeled together in a certain shape and then displayed on a banana tree in front of the mosque called pajegan. The egg series was originally formed and decorated with colors to resemble a temple, calloused ship, bonsai tree or camel animal. Male is usually used as a gift for the invitees and the people who attend the event. He was also later presented at the baby birth ceremony as a blessing and gratitude to God (S. Saihu, 2019).

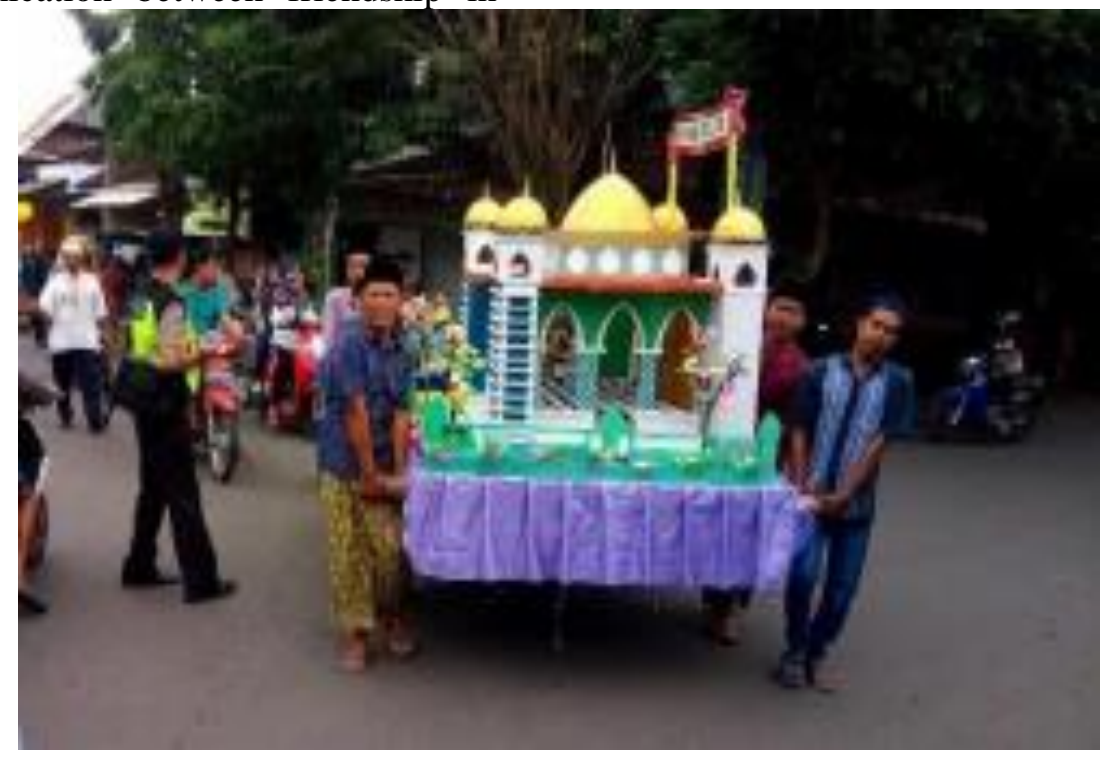

The tradition of male during the celebration of the Prophet's birth usually begins with a tour of the village by bringing colorful egg decorations in various forms. Male was then paraded by the community escorted by a security officer in Balinese traditional clothing named pager uyung. These security guards are not only from Muslims, but also from Hindus called pecalang. Like the commemoration of welcoming the Prophet's birth, Muslims go around reading asrakal, a type of salawat and praise while beating tambourines and marawis.

After finishing around the village, all the decorations male were collected at the mosque. The eggs are then stabbed with bamboo and stuck into the 
banana tree. This is what is called pajegan. From a distance it looks like a banana tree bearing eggs. After being displayed, the congregation recites the salawat $d i b a^{\prime}$ which tells of the Prophet's life journey as an expression of love for him. The recitation of the salawat ends by distributing eggs pajegan to Muslim and Hindu congregations. People usually scramble and jostle to get the egg, considering it a blessing, because Islamic religious leaders have recited it. According to KH. Ahmad Muzakki, Chair of the Jembrana MUI, said that the tradition contains the value of goodness in order to create harmony between religions. It contains at least three meanings, that is aesthetic, ethical and social. Aesthetically, men show a culture that is nuanced art by reciting salawat and singing praises to the Prophet. In ethics, the procession male around dressed with traditional Balinese show that Muslims asked permission to residents the majority of Hindus to carry out the day warning the Muslims. Therefore, Muslims formed Male not only with the distinctive form of the Islamic symbol, but also in the form of a temple. More ever, pecalang from the Hindu community also participated in the security around the village. This shows that even though the male tradition is carried out by Muslims, Balinese traditional nuances are a form of cultural multiculturalism for the sake of creating harmony.

The same thing was conveyed by Ida Bagus Arnawa, a Hindu religious leader, who said: "It is not only help to Muslims that Hindus give (as seen in the male tradition), on the contrary every time I hold a religious ceremony, my Muslim friends. Participate and help prepare the equipment or facilities that I need for the ceremony. Different beliefs do not limit me to always communicate and cooperate in social relationships. The important thing is to live in harmony, help each other, because if you are in harmony, of course, God will make it easy to achieve material prosperity (Interview with Ida Bagus Putu Arnawa, April $7^{\text {th }}$ 2019).

The meaning of ethics is then also closely related to social meaning in which the Hindu-Muslim community feels socially bound to respect each other's culture and religious traditions. Therefore, if during the male tradition, Hindus take part in maintaining security and are present in the distribution of male eggs during the Muslim celebration, then Muslims will also be involved in maintaining security during Hindu religious celebrations, such as Nyepi, Kuningan and Galungan (Interview with KH. Ahmad Muzakki, March $4^{\text {th }}$ 2019). The effort to respect each other in religious celebrations between the Hindu majority and the Muslim minority is a form of awareness in maintaining harmony within the framework of the dominant culture in Jembrana Bali. The male form resembles a temple, the involvement of the pecalang,
Balinese traditional clothing and the presence of Hindus in obtaining male eggs show respect for this dominant culture by Muslims. A tradition based on shared awareness to live harmoniously in diversity. Hindu-Balinese in Jembrana realize that even though they have different religions, these differences do not become an obstacle to living harmoniously in creating a peaceful society.

Those are some forms of local traditions as a reflection of the manifestation of harmony between religious communities in Jembrana Bali, in the form Ngejot and Male. All these local traditions are not only carried out by Hindus or Muslims, but always involve the two religious communities. More ever, in this practice, all these traditions are also dominated by the characteristics of Balinese customs as the dominant culture that is guarded and maintained by the Jembrana people. Theologically, in Hindu belief, some of these local traditions are manifestations of the teachings of the Tri Hita Karana (parahyangan, pawongan and palemahan, the relationship with God, man and nature). The three of them reinforce the view that humanity is one brother who is known among Balinese by the expression tatwam asi (you are me and I am you) (Interview with I Komang Arsana, April $4^{\text {th }}$ 2019). The same thing is also believed in Islamic teachings which encourage the establishment of good relations with God, humans and nature, hablumminallah, habluminannas and hablumminal'alam.

In the perspective of the theory of religion as a cultural system, as stated by Geertz at the beginning, the local tradition has become a substantive model that reflects the reality of the relationship between ethnic groups and religions in the context of local power structures. A power that is manifested in the form of religious and cultural relations so that it is highly respected by all religious adherents in Jembrana. Therefore, the harmony that is built is basically very much determined by the respect for the local culture, especially by the immigrant minority so that they are involved in maintaining the local power structure. The Muslim community as a minority tries to adapt to the local culture prevailing in Jembrana so that interethnic harmony can be realized.

\section{CONCLUSION}

This study shows that local traditions contribute to maintaining harmony between religious communities through respect for local culture. The Hindu-Muslim community in Jembrana practices it in the Ngejot and Male traditions. Although this tradition originates from a certain religion, the two religious communities try to be involved in it. The HinduMuslim community is equally aware of the importance of their involvement in this local tradition. However, 
this study also shows the importance of respect for the dominant culture practiced by Muslim minorities when carrying out their religious traditions. Although the male tradition, for example, originates from the Islamic tradition, cultural influences are able to encourage adjustments to Balinese customs so that harmony is easier to maintain. Here the Muslims ed in several conflict areas in Indonesia. Therefore, culture is one of the important keys in understanding local traditions in the context of ethnic and religious differences. A multiculturalism educational perspective that places the diversity of local traditions as a symbol of communication between cultures and religions in Indonesia.

\section{Bibliography}

Astuti, H. J. P. (2017). Islam Nusantara: Sebuah Argumentasi Beragama dalam Bingkai Kultural. NJECT:Interdisciplinary Journal of Communication, 2(1), 27-52.

Azra, A. (2002). Reposisi Hubungan Agama dan Negara: Merajut Hubungan antar Umat. Jakarta: Kompas.

Baharun, H. (2018). Tradisi Ngejot: Sebuah Ekspresi Keharmonisan dan Kerukunan antar Umat Beragama dengan dakwah bil hal. Fenomena, 10(1), 1-26.

Bailey, K. D. (1982). Methods of Social Research. New York: A Division of Macmillan Publishing Co. Inc.

Basyir, K. (2016). Membangun Kerukunan antarumat Beragama Berbasis Budaya Lokal Menyama Braya di Denpasar Bali. Religio, 6(2).

Beyers, J. (2017). Religion and culture: Revisiting a close relative. HTS Theological Studies, 73(1), 1.

Geertz, C. (1973). Thick Description: Toward an Interpretative Theory of Culture in Geetrtz, The Interpretative of Cultures: Selected Essay. New York: Basic Book.

Geertz, C. (1993). Religion as a cultural system. In The interpretation of cultures: selected essays (p. 90). New York: Fontana Press.

Guba, Y. S. L. dan E. G. (1985). Naturalistic Inquiry. Newbury Park: SAGE.

I Gede Suwindia, M. dan I. G. P. (2012). Relasi Islam dan Hindu Perspektif Masyarakat Bali. Al-Ulum, 12(1), 53-76.

Karim, M. A. (2016). "Toleransi Umat Beragama di Desa Loloan, Jembrana, Bali." Analisis, XVI(1), $1-30$.

Knopp, R. B. B. and S. (1998). Qualitative Research for Education: An Introduction to Theory and Methods. Boston: Allyn and Bacon.

Kobylarek, A. (2014). Education and Culture Society. International Scientific Journal, (2), 44. understand their position to protect and respect the culture followed by the majority of Hindus in Jembrana Bali. Without respect for local culture, relations between ethnicities and religions may lead to competition which can lead to conflict and conflict, as hashappen

Maknun, M. L. (2018). Harmoni Hindu-Muslim Berbasis Tradisi Lisan Sejarah Desa Saren Budakeling Karangasem Bali. FIKRAH, 6(2), 341.

Marc Helbling, R. T. (2016). How State Support of Religion Shapes Attitudes Toward Muslim Immigrants: New Evidence From a Sub-National Comparison. Comparative Political Studies, 49(3), 391-424.

Michael, M. M. H. and. (1992). Analisis data Kualitatif. Jakarta: Universitas Indonesia.

Michalinos Z, Z. B. (2013). Peace education in the present: dismantling and reconstructing some fundamental theoretical premises. Journal of Peace Education, (10), 543-556.

Mubit, R. (2016). Peran Agama dalam Multikulturalisme Masyarakat Indonesia. Episteme, 11(163-184).

Mulyana, D. (2002). Metodologi Penelitian Kualitatif: Paradigma Baru Ilmu Komunikasi dan Ilmu Sosial Lainnya. Bandung: Remaja Rosdakarya.

P., B. J. (2019). Emergence of Religious Radicalism and Violent Extremism:Historical Roots and Contemporary Trends in Kenyawith a Focus on Al Shabaab. African Multidisciplinary Journal of Research (AMJR)., 4(1), 130-156.

Pageh, I. M. (2018). Kearifan Sistem Religi Lokal dalam Mengintegrasikan Umat Hindu-Islam di Bali. Jurnal Sejarah Citra Lekha, 3(2), 88.

Pageh, I Made. (2013). Faktor Integratif Nyama BaliNyama Selam: Model Kerukunan Masyarakat pada Era Otonomi Daerah di Bali. Jurnal Kajian Bali, 3(1), 191-206.

Pals, D. L. (2011). Seven Theories of Religion. Jogjakarta: IRCiSoD.

Rusmayani, R., \& Gunawan, A. H. (2018). Hubungan Mayoritas Hindu Bali terhadap Minoritas Muslim (Studi Toleransi Puri Pemecutan Terhadap Komunitas Minoritas Muslim di Kampung Bugis Serangan, Denpasar- Bali). Ngabari: Jurnal Studi Islam Dan Sosial, 11(1), 16-36.

Sabarudin dan Mahmud Arif. (2019). Kerukunan Hidup antar Umat Beragama berbasis Kearifan Lokal. Sosiologi Reflektif, 14(1), 89.

Saihu. (2020). Local Tradition and Harmony among Religious Adherents: the Dominant Culture of Hindu-Muslim Relation in Jembrana Bali. Wawasan: Jurnal Ilmiah Agama Dan Sosial Agama, 5(1), 32-42. 
Saihu, A. M. (2019). Teori pendidikan behavioristik pembentukan karakter masyarakat muslim dalam tradisi Ngejot di Bali. Ta'dibuna, 8(2), 168.

Saihu, S. (2019). Pendidikan Karakter Berbasis Kearifan Lokal (Studi Di Jembrana Bali). Edukasi Islami: Jurnal Pendidikan Islam, 8(01), 69-90. https://doi.org/10.30868/ei.v8i01.364

Saihu, \& Sahin, C. (2020). The Harmonious Dialectics Between Hindu-Muslim in Bali (A Study in Jembrana Regency). Religia Jurnal Ilmu-Ilmu Keislaman, 80(1), 56-80.

Sumiati, D. (2017). Intercultural Communication Based on Local Wisdom That Made the People of Bali Reject Sharia Tourism. Asian Journal of Media and Communication, 1(2), 137-146.

Vickers, A. (1987). Hinduism and Islam in Indonesia: Bali and the Pasisir World. Indonesia, 44, 31-58.

Vitchek, A. (2012). Indonesia, Archipelago of Fear. New York: Pluto Press.

Wikan, U. (1990). Managing Turbulent Hearts: A Balinese Formula for Living. Chicago: The University of Chicago Press.

Yohanes S Lon, F. W. (2019). Food and Local Social Harmony: Pork, Communal Dining, and MuslimChristian Relations in Flores, Indonesia. Studia Islamika, 26(3), 445-474. 